\title{
SURFACE CHARACTERIZATION AND CYTOTOXICITY ANALYSIS OF THE TITANIUM ALLOYS FOR DENTISTRY
}

\author{
PAULA ARGENTINA JIMAN ${ }^{a, b}$, MARIOARA MOLDOVAN", \\ CODRUTA SAROSI ${ }^{*}$, ALEXANDRINA MUNTEAN ${ }^{a}$, \\ ANDREEA SIMONA POPa, VIORICA TARMURE ${ }^{a}$, \\ CATALIN POPA $^{b}$, AUREL GEORGE MOHAN ${ }^{d}$
}

\begin{abstract}
Three methods of treating the Ti and Ti-6Al-4V alloy surface used as dental implants have been tried both to increase the corrosion resistance and to create diffusion barriers, which prevent the release of toxic ions in the body, at the separation surface, implant living tissue. The anticorrosive performances of the experimental oxide films, realized on the pure $\mathrm{Ti}$ and Ti-6Al-4V alloy were evaluated electrochemically by cyclic voltammetry after immersion of samples in Ringer's solution at $37^{\circ} \mathrm{C}$. The A2-Ti sample (Ti-6Al-4V alloy anodized with $\mathrm{H}_{3} \mathrm{PO}_{4}, 1 \mathrm{~N}$, and citric acid, $20 \mathrm{~g} / \mathrm{l}$ electrolyte solution) shows lower viability values, compared to the other samples, with a tendency to decrease after $48 \mathrm{~h}$ of incubation. The cytotoxic effect is slightly higher in A1-Ti (Ti-6Al-4V alloy anodized with $0.6 \% \mathrm{H}_{3} \mathrm{PO}_{4}$ electrolyte solution) compared to $\mathrm{Ti}$ over a period. This can be attributed to the presence of aluminium and vanadium. The results revealed that the specific processing of titanium and titanium alloy (Ti-6Al-4V) by obtaining an oxide layer influence the toxicity that is stabilize and decrease with time, which makes to be used in dental implantology.
\end{abstract}

Keywords: Ti-6Al-4V surface treatment, electrochemical processing, dental implant, cytotoxicity, SEM.

a Iuliu Hatieganu University of Medicine and Pharmacy, Faculty of Dentistry, 31 A. lancu Street, RO-400083, Cluj-Napoca, Romania

b Technical University of Cluj-Napoca, Faculty of Materials Science and Engineering, ClujNapoca, Romania

c Babeş-Bolyai University, Institute of Chemistry Raluca Ripan, 30 Fantanele Str., RO-400294, Cluj-Napoca, Romania

d University of Oradea, 1 Universitatii Street, RO-410087, Oradea, Romania

* Corresponding author: codruta.sarosi@ubbcluj.ro 
PAULA ARGENTINA JIMAN, MARIOARA MOLDOVAN, CODRUTA SAROSI, ALEXANDRINA MUNTEAN, ANDREEA SIMONA POP, VIORICA TARMURE, CATALIN POPA, AUREL GEORGE MOHAN

\section{INTRODUCTION}

The metallic alloys currently used to manufacture implants for corrective surgery of orofacial deformities and defects, are bioinert materials when in contact with human bone tissue, which can become bioactive by controlling the morphology of the chemical composition of the surface [1,2]. The type of material, method of production, chemical composition and mechanical properties of the material influence the interaction between bone and implant and longterm stability is closely related to its integration into the remnant bone [3-6].

Titanium is used extensively in surgery, due to its good biocompatibility, explained by its physical and mechanical properties and by the fact that the surface of titanium is always covered with an $\mathrm{TiO}_{2}$ layer $[6,7]$. This nanometric layer is responsible for the materials' resistance to corrosion and its bioinert behavior in vivo, which leads to an acceptable osseointegration. Currently, implants are processed through additve and substractive manufacturing $[8,9]$. After manufacturing, the surfaces of the implants are modified by: sandblasting, etching, anodizing, depositing of biocomposites or chemical treatments. Each of these methods have been used to improve the stability and facilitate the process of osseointegration [10-12]. Furthermore, it was demonstrated that the implant surface topography can certainly help the cellular and molecular mechanisms [13]. Porous surfaces showed better absorption of biomolecules in biological fluids and in vitro tests indicate that porous surfaces enhance bone cell response [14-16]. Rigidity and crystallization directly affects surface receptors on the cell surface and focal points, triggering a cascade of intracellular signals that determines activation of specific genetics [17]. Basically, by changing longitudinal modulus of elasticity of the implant, cell differentiation can be improved. If the balance of rigidity is achieved both by the metal structure of the implant and the bone tissue, the risk of adverse effects is very small. Several studies present that the functionalisation of the metallic implants surface that are in direct contact with bone with bioceramic is a good solution. Bioceramic presents advantages such as: absence of corrosion, absence of release of metal ions which are very harmful for the organism, more resistance to tearing and greater resistance to fatigue $[18,19]$. A major importance is represented by the bonding between the bioceramics and metallic implant structure $[20,21,22]$.

Changes in the titanium surface and titanium alloys used in the medical field can considerably affect the process of osteointegration of dental implants in contact with the organic environment. In particular, the morphology of the surfaces can be a key factor in the colonization and adhesion of osteoblasts to the bone-implant contact surface. Recent world studies have considered the development of functional groups on the surface of titanium and titanium alloys capable of inducing and improving the process of bone tissue formation (osteoblast adhesion, hydroxyapatite crystal nucleation process). It is hoped 
that by these treatments the duration of the process of osteointegration will be substantially reduced and the quality of the connections obtained will be substantially improved [23].

The response of cells and tissues to the interface may be affected by the topography or surface geometry at the macro level, as well as its morphology and roughness at the micro level. Also, a particular influence may have the crystalline structure at the atomic level [24,25]. The crystalline structure is the result of numerous treatments either mechanical, chemical, thermal, or combinations thereof. The different forms of the crystalline structure can be a great control to ensure the successful osseointegration of the implants made of titanium and its alloys [26,27].

The purpose of this study is to determine the optimum electrochemical and thermochemical processing of $\mathrm{Ti}$ and the Ti-6Al-4V, titanium alloy, in order to obtain surfaces with high inertia and high chemical configurations, capable of creating strong and stable bonds with bone tissues at the implantbone interface. The newly created surfaces should favor the growth of the osteoblasts and the interaction of the bone tissue with the implanted material.

\section{RESULTS AND DISCUSSION}

Electrochemical investigations regarding the anticorrosive performances of the experimental oxide layers realized on the Ti-6Al-4V alloy

The anticorrosive performances of the experimental oxide films, realized on the pure Ti and Ti-6Al-4V alloy were evaluated electrochemically. The analysis is a comparative one, the reference being each time, the Ti-6Al-4V alloy, mechanically polished. The results obtained by cyclic voltammetry are presented in table 1.

Table 1. Electrochemical characteristics of investigated samples, polished, without anodizing

\begin{tabular}{|c|c|c|c|c|c|c|c|c|c|}
\hline$\frac{\mathscr{\infty}}{\frac{\infty}{0}}$ & 焉 & 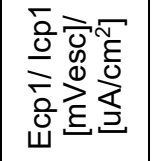 & 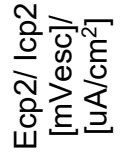 & 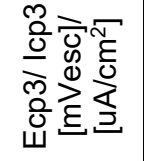 & 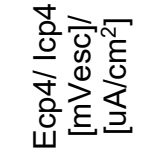 & 离 & 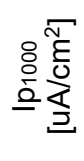 & 을 & 卢导 \\
\hline \multirow[t]{2}{*}{ A1-Ti } & -505 & $-456 / 14$ & - & $1079 / 235$ & $3100 / 2500$ & 39 & 228 & 4125 & 2700 \\
\hline & 1080 & $-682 /-711$ & $-5 /-72$ & - & - & -9 & -2 & & \\
\hline \multirow[t]{2}{*}{ A2-Ti } & 1500 & - & - & - & - & - & -5 & -3 & 14 \\
\hline & 1862 & - & - & - & - & - & -7 & -5 & \\
\hline \multirow[t]{2}{*}{$\overline{T i}$} & -510 & $-445 / 22$ & $210 / 64$ & $1100 / 290$ & $3100 / 3330$ & 80 & 270 & 5000 & 2400 \\
\hline & 576 & $\mid-680 /-770$ & $10 /-70$ & - & - & -10 & 0 & & \\
\hline
\end{tabular}

${ }^{*} \mathrm{~A} 1-\mathrm{Ti}, \mathrm{A} 2-\mathrm{Ti}, \mathrm{Ti}$, see in the Table 2. 
The electrochemical characteristics evaluated are the mixed corrosion potential $E_{m c}$, the critical passivation potentials and currents, $E_{c p}$ respectively $I_{c p}$, the passivity current $I_{p}$, at 500,1000 and $4000 \mathrm{mVe.s.c.} \mathrm{and} \mathrm{the} \mathrm{potential}$ of $\mathrm{E}_{\mathrm{T}}$ transferability. In a separate row (and highlighted by a tint of color), for each sample and the specific values of the return curve were noted. These maxima may indicate the reversibility of oxidative anodic processes. The difference between the mixed corrosion potential and the potential to return to the cathode is a measure of the ennobling due to the anodic polarization and the electrochemical passivization of the investigated surface.

Table 1 shows the behavior of titanium and Ti-6Al-4V alloy in Ringer's solution at $37^{\circ} \mathrm{C}$. Besides the oxidation in three or four stages, the specificity of both materials is compared, a decrease in the amplitude and complexity of the anodic process is realized, a single critical potential, Ecp1

The experimental data generally indicate better anticorrosive performances in the case of the alloy than in the case of pure titanium, and the mixed corrosion potential is more noble in the case of the alloy, $-505 \mathrm{mVe}$.s.c. the others at $-510 \mathrm{mVe}$.s.c. in the case of the titanium.

Representative samples A1-Ti and A2-Ti show a greater electrochemical inertia and we used for representation a current scale of max. $0,1 \mu \mathrm{A} / \mathrm{cm}^{2}$. The electrochemical characteristics presented in table 1 lead to the conclusion that these samples have excellent anticorrosive performances. The A1-Ti and A2-Ti samples have excellent performances, do not exhibit electrochemical passivation processes, they do not have a mixed corrosion potential, in a predictable field, considering the chemical composition of the estimated substrate of the oxide film; the samples behave as an ohmic resistance, the current / potential relationship is practically linear, nor can a potential for trans-passivity be estimated $[28,7,8]$. All samples have significantly lower anodic densities than those recorded for the polished alloy.

\section{Study of the oxide layers obtained on $\mathrm{Ti}$ and $\mathrm{Ti}-6 \mathrm{Al}-4 \mathrm{~V}$ alloy by electrochemical techniques, using scanning electron microscopy}

The samples were studied using the Inspect $S$ scanning electron microscope, FEY Company. The morphology of the experimental oxide layers made on titanium and Ti-6Al-4V alloy was followed by electrochemical oxidation techniques.

The oxide layer has a continuous appearance with many excrescences in the form of small islands and has a good adhesion on the support. The images in fig. 1 show the most characteristic aspects of the studied layer. 

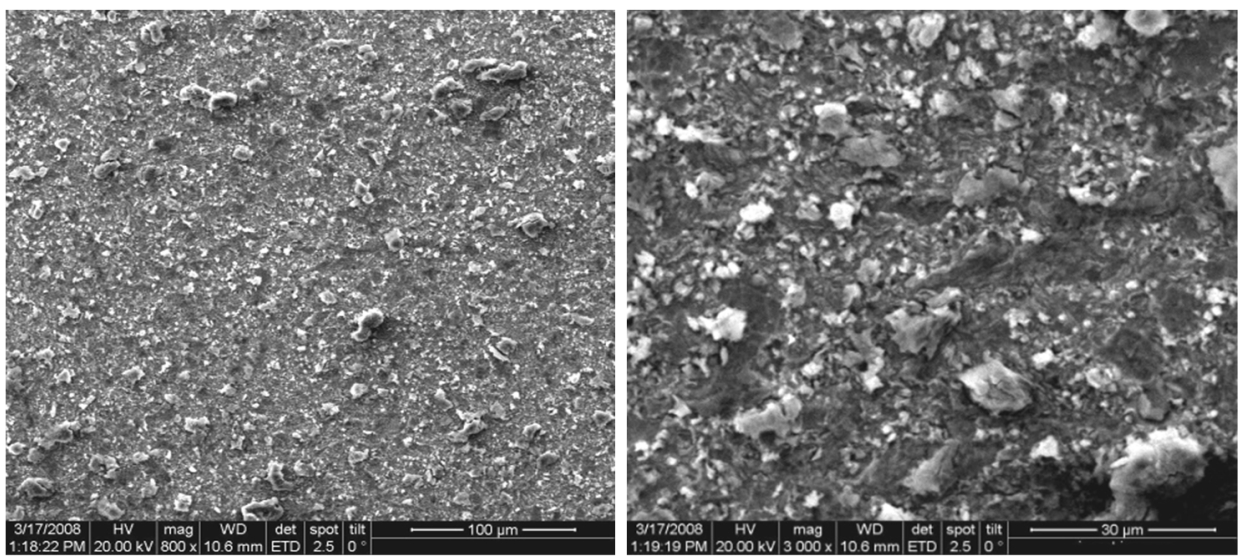

Figure 1. SEM images of the surface of A1-Ti sample after the anodizing with $\mathrm{H}_{3} \mathrm{PO}_{4}$ electrolyte solution $0,6 \%$ and treated at $760^{\circ} \mathrm{C}$ for 5 min, captured with $800 x$ and $3000 x$ magnification

From the morphological point of view, the layer presents itself as a continuous deposit with a soluble appearance that is easily contaminated in the electron beam. This contamination indicates in this case a poor electrical conductibility of the layer. The images from fig. 2 present the aspects characteristic of this deposit.
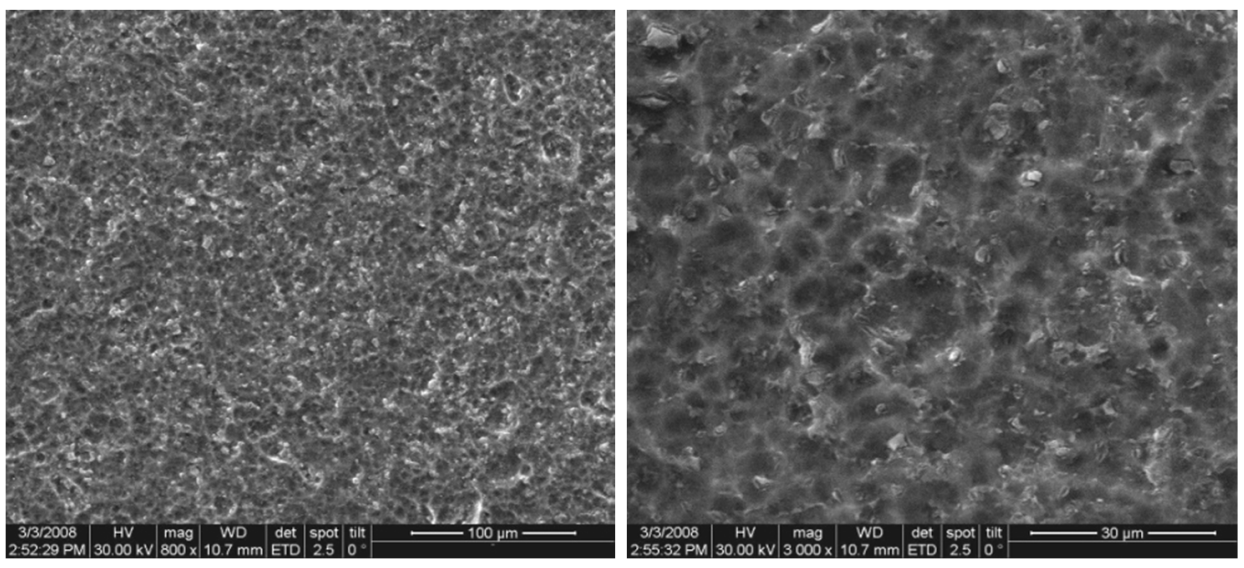

Figure 2. SEM images of the surface of A2-Ti sample after the anodizing with $\mathrm{H}_{3} \mathrm{PO}_{4} 1 \mathrm{~N}+20 \mathrm{~g} / \mathrm{l}$ citric acid electrolyte solution and treated at $360^{\circ} \mathrm{C}$ for $5 \mathrm{~min}$, captured with $800 x$ and $3000 x$ magnification 

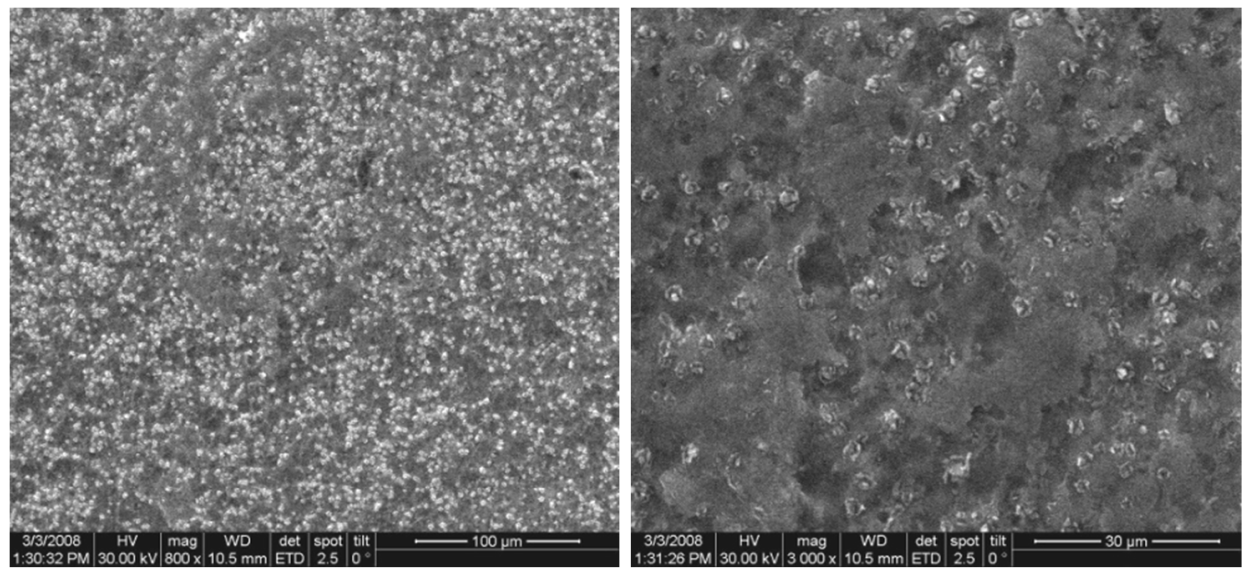

Figure 3. SEM images of the surface of Ti sample after the electrolytic oxidation, captured with $800 x$ and $3000 x$ magnification

After immersion in the Ringer solution, the surfaces of the samples are presented in Figure 4, 5 and 6.
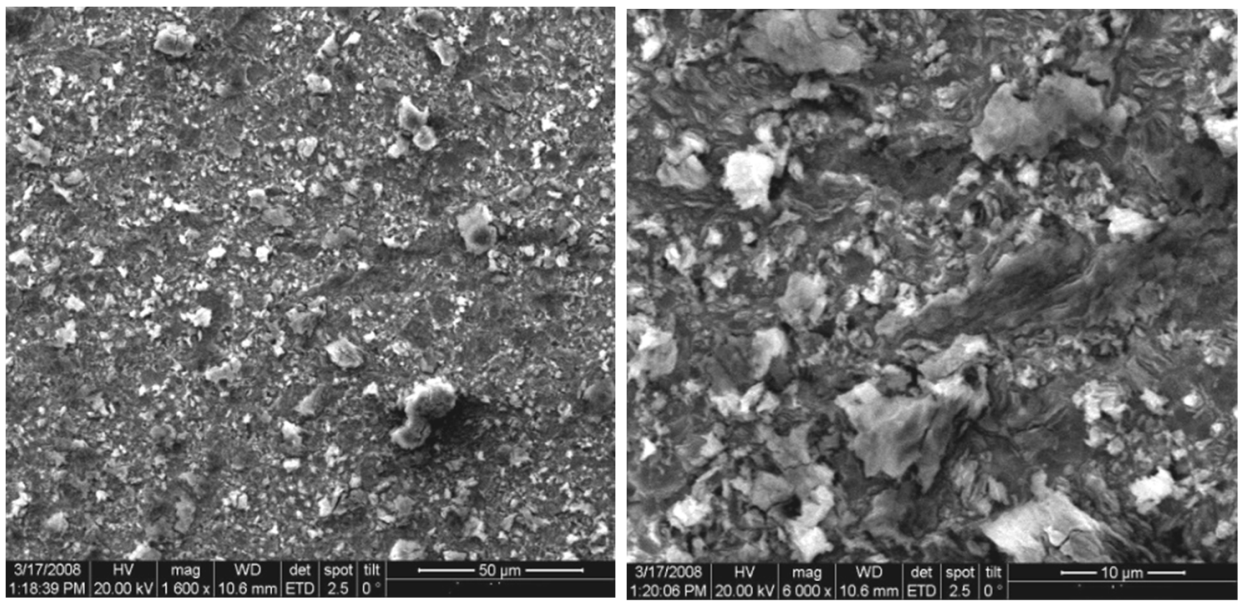

Figure 4. SEM images of the surface of A1-Ti sample after electrochemical investigations regarding the anticorrosive performances in Ringer solution, captured with $1600 x$ and $6000 x$ magnification

From the presented research study it results that the samples of titanium alloy Ti-6Al-4V show a high chemical inertia in Ringer synthetic liquid, following the specific electrochemical and thermochemical processes performed at the surface level. 

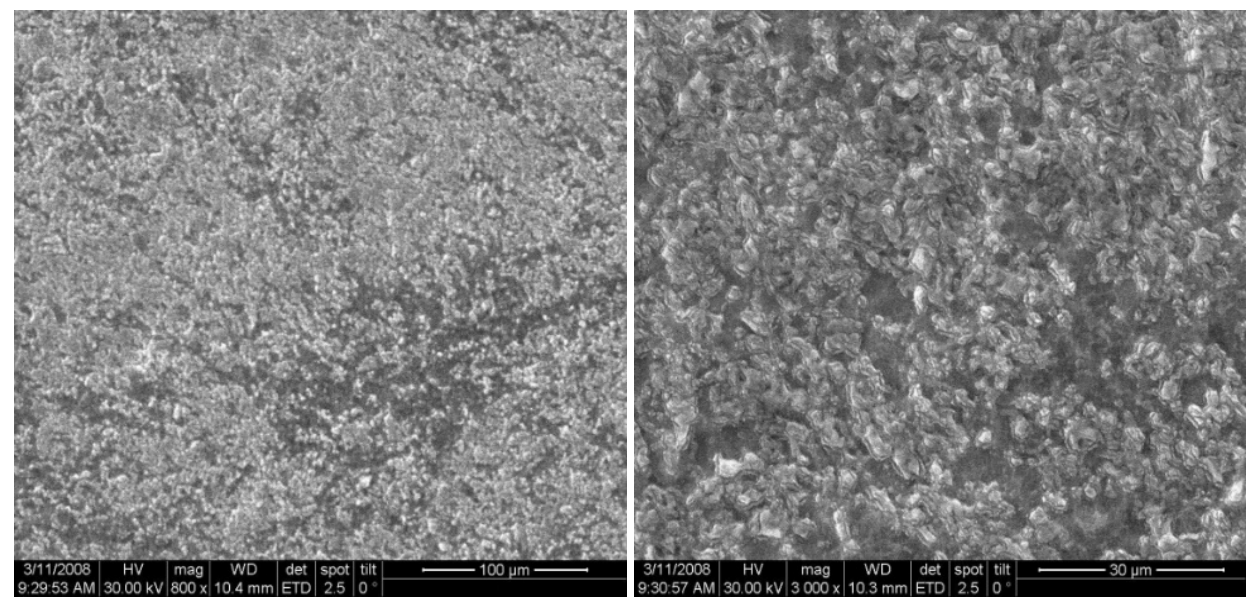

Figure 5. SEM images of the surface of A2-Ti sample after electrochemical investigations regarding the anticorrosive performances in Ringer solution, captured with $800 x$ and $3000 x$ magnification
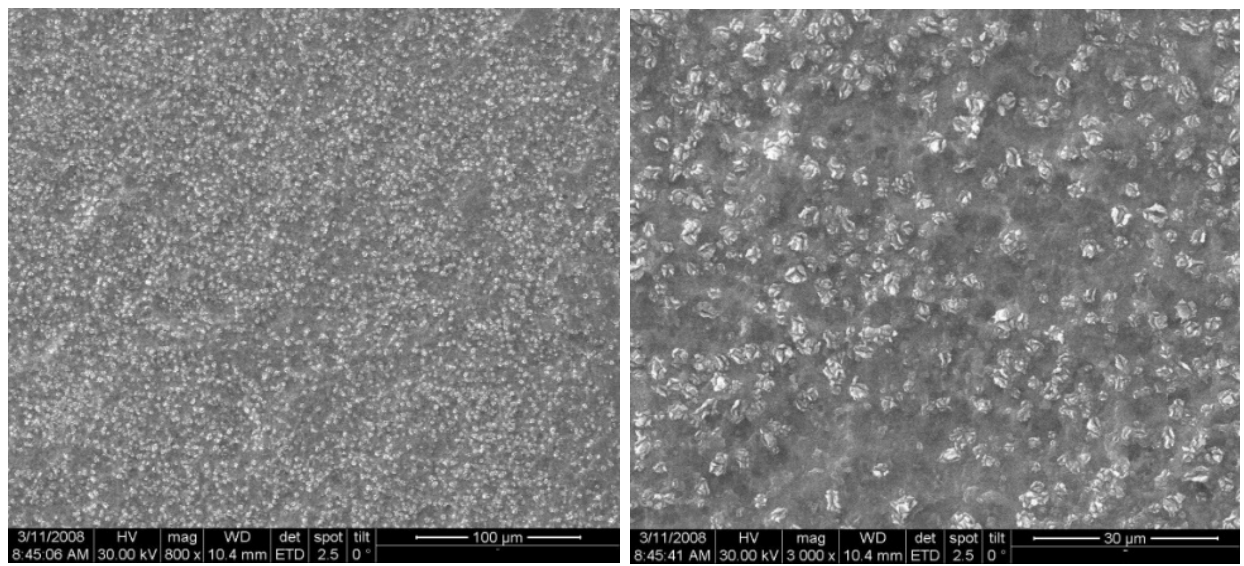

Figure 6. SEM images of the surface of Ti sample after electrochemical investigations regarding the anticorrosive performances in Ringer solution, captured with $800 x$ and $3000 x$ magnification

Different types of titanium oxide-based structures with amorphous or crystalline structure such as anatase and rutile have been obtained, doped with phosphorus-based compounds, which can be real diffusion barriers for potential toxic aluminum and vanadium ions at the contact of the implant with the organic environment [23,29-31]. 
The obtained configurations will have to lead to the growth and adhesion of the osteoblast cells in order to make a solid connection at the implant-bone interface level $[10,11,30]$.

Specific tests of cell growth and implantology will continue to be performed to study the compatibility of the studied alloy with the environment and oral tissues.

Viability test of normal human fibroblasts treated with fully incubated
media with experimental titanium alloy samples for 24 and $48 \mathrm{~h}$

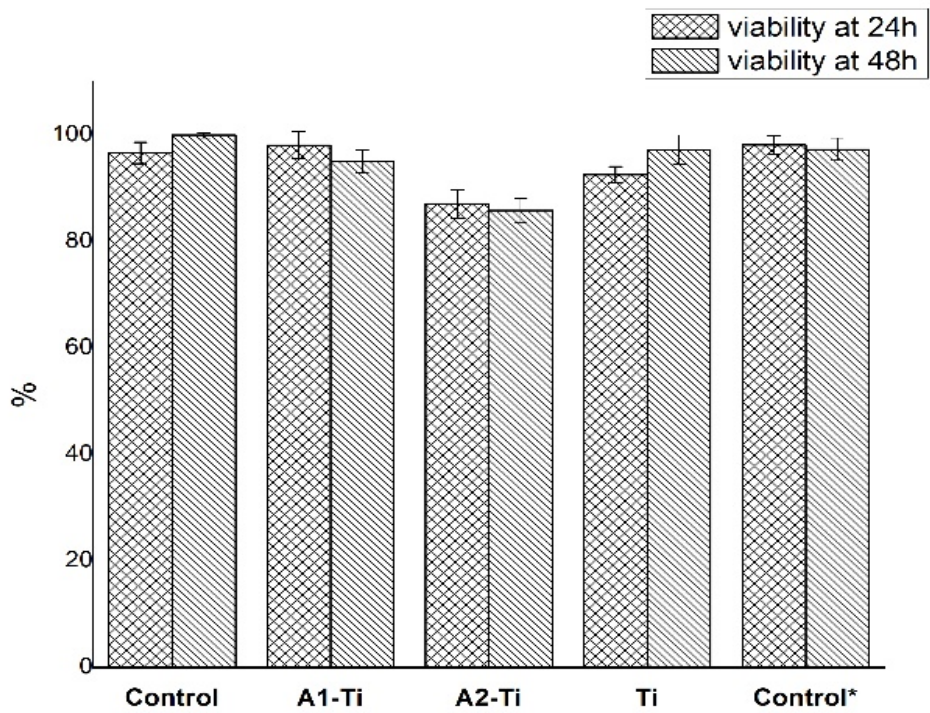

Figure 7. Comparison of the viability of fibroblasts exposed to the incubated environment of the studied samples for 24 and $48 \mathrm{~h}$. *untreated control is represented only by the complete fibroblast environment (the liquid component represented by the biological environment).

The A2-Ti sample shows lower viability values, compared to the other samples, with a tendency to decrease after $48 \mathrm{~h}$ of incubation.

The cytotoxic effect is slightly more in A1-Ti compared to Ti over a period. This can be attributed to the presence of aluminum and vanadium. $[7,11,32,33]$ However, the effect of toxicity was found to stabilize and decrease with time. The increase of $\mathrm{TiO}_{2}$ passivating layer over a period of time, which is formed in contact with tissue cells, moderated the toxicity by curtailing the release of $\mathrm{Ti}, \mathrm{Al}$, and $\mathrm{V}$ ions from test materials into the tissue cells. [34,35] 


\section{CONCLUSIONS}

A research study was conducted on the specific processing of titanium and titanium alloy Ti-6Al-4V for use in dental implantology.

Electrochemical evaluations indicate a good stability of these experimental interfaces in synthetic biological solutions. The morphology of the sample surface, generally alveolar and favorable for cell growth at the interface, represents an interesting premise in the continuation of this research direction.

The electrochemical methods of treating the surface of samples by controlled anodization processes, in electrolytes compatible with its structure and its physico-chemical characteristics, have generated at the surface level oxide layers formed from titanium oxides having the role of diffusion barrier and anticorrosive protection, which can contribute to increasing the biocompatibility of implants in the body and to improving the characteristics of rapid osteointegration. Both the titanium and the Ti-6Al-4V alloy behaved well from the electrochemical point of view in the electrolysis solutions, their behavior being similar.

The chemical surface treatment methods did not lead to obtaining anti-corrosion protection layers on the titanium and Ti-6Al-4V alloy samples. The surface of the samples is active, does not have passivity properties and cannot attribute to the applied chemical treatments any ability to protect the titanium base. To a large extent, these samples behave just like pure titanium.

Surface properties analyzed by scanning electron microscopy revealed the existence of an compact, uniform and adherent titanium oxide layer. The oxide layer had a slim appearance, this contributing to a better growth of the tissue on the implant, and to a better anchorage of the dental implant.

These surface properties justify that the sandblasted implants is able to significantly increase bone contact and bone growth with very good osseointegration results in vivo.

\section{EXPERIMENTAL}

\section{Sample preparation}

$\mathrm{Ti}$ and Ti-6Al-4V alloy with the following composition was used (\%): Ti=base; $\mathrm{N}=0,0051 ; \quad \mathrm{C}=0,030 ; \quad \mathrm{Al}=5,53 ; \quad \mathrm{V}=3,90 ; \quad \mathrm{Fe}=0,13 ; \mathrm{Si}=0,05-0,1$; $\mathrm{Ni}=0,01-0,05 ; \mathrm{Cr}=0,005-0,01 ; \mathrm{Co}<0,005 ; \mathrm{Cu} \cong 0,001$.

15 samples of Ti-6Al-4V with dimmension $28 \times 20 \times 0.5 \mathrm{~mm}$ were analysed. The surface of samples were mechanicaly prepared (polishing with metallographic paper 150-400 granulation; washing with usual hot water; washing with distilled water; hot air drying) followed by degreasing with acetone and ethyl alcohol and 
finally the pickling treatment (pickling - depasivation with HF (1\%; 20\%), HF6\% + $\mathrm{HNO}_{3} 23 \%$; washing with usual hot water; washing with distilled water; hot air drying).

After the preparation the samples obtained were subjected to electrochemical treatments as are presented in table 2.

The electrolytic oxidation of the titanium, its anodization, is a process of artificial creation, of growth on the surface of the titanium a oxide layers, of course of much greater thicknesses than the natural layer, which is realized spontaneously on the titanium.

In this process, the titanium represents the anode, the cathode being represented by metals such as $\mathrm{Pb}, \mathrm{Al}$, chemically stable metals in the electrolytes used. The anodic reaction is an oxidation process that takes place on the surface of the anode (titanium anode): $\mathrm{R}_{\mathrm{A}}: \mathrm{Ti}+2 \mathrm{H}_{2} \mathrm{O} \rightarrow \mathrm{TiO}_{2}+4 \mathrm{H}+4 \mathrm{e}^{-}$.

The cathodic reaction is a reduction process that occurs on the cathode surface $(\mathrm{Pb}, \mathrm{Al}): \mathrm{R}_{\mathrm{K}}: 4 \mathrm{H}+4 \mathrm{e}^{-} \rightarrow 2 \mathrm{H}_{2(\mathrm{~g})}$.

Table 2. Ti and Ti-6Al-4V alloy samples subjected to electrochemical treatments (controlled anodization in electrolytes compatible with the processed material).

\begin{tabular}{|l|l|c|}
\hline \multicolumn{1}{|c|}{ Sample } & \multicolumn{1}{|c|}{ Sample preparation } & $\begin{array}{c}\text { Heat treatment } \\
\text { * in air }\end{array}$ \\
\hline $\mathrm{Ti}-6 \mathrm{Al}-4 \mathrm{~V}$ alloy & $\begin{array}{l}\text { Anodizing with } \\
\text { electrolyte solution } 0.6 \% \mathrm{H}_{3} \mathrm{PO}_{4}\end{array}$ & $760^{\circ} \mathrm{C}, 5 \mathrm{~min}$. \\
& $\mathrm{U}(\mathrm{Vcc})=30, \mathrm{Is}=40(\mathrm{~mA}), 30 \mathrm{~min} ., 60^{\circ} \mathrm{C}$ & \\
\hline $\mathrm{Ti}-6 \mathrm{Al}-4 \mathrm{~V}$ alloy & $\begin{array}{l}\text { Anodizing with } \\
\text { A2-Ti }\end{array}$ & $\begin{array}{l}350^{\circ} \mathrm{C}, 60 \mathrm{~min} . \\
\text { electrolyte solution } \mathrm{H}_{3} \mathrm{PO}_{4} 1 \mathrm{~N}+20 \mathrm{~g} / \mathrm{l} \text { citric acid } \\
\text { solution (ratio 1: } 1)\end{array}$ \\
& $\mathrm{U}(\mathrm{Vcc})=50, \mathrm{O}=0.5(\mathrm{~mA}), 120 \mathrm{~min} ., 25^{\circ} \mathrm{C}$ & \\
\hline $\mathrm{Ti}$ & Purity $99,9 \%$ & - \\
\hline
\end{tabular}

\section{Electrochemical investigations regarding the anticorrosive performances of the $\mathrm{Ti}$ and TA6V4 alloy}

The experimental technique used is cyclic voltammetry. Sample and storage parameters have been set: the sample time $1000 \times 100 \mu \mathrm{sec}$., the scale head for current $0.1,0.5$ or $1 \mathrm{~mA}$. The surface investigated of the samples was $0.2 \mathrm{~cm}^{2}$.

The electrolyte used was a synthetic biological solution, the Ringer solution, table 3 , a complex solution with a high content of $\mathrm{Cl}^{-}$ions. $\mathrm{pH} 2.5$ was established by acidification with hydrochloric acid. 
Table 3. Synthetic biological solutions

\begin{tabular}{|c|c|c|c|c|}
\hline $\begin{array}{c}\text { Components } \\
{[\mathrm{g} / \mathrm{l}]}\end{array}$ & Hank Solution & $\begin{array}{c}\text { Ringer } \\
\text { Solution }\end{array}$ & $\begin{array}{c}\text { Artificial physiological } \\
\text { solution }\end{array}$ & $\begin{array}{c}\text { Artificial } \\
\text { saliva }\end{array}$ \\
\hline $\mathrm{NaCl}$ & 8 & 8 & 8,44 & - \\
$\mathrm{KCl}$ & 0,40 & 0,4 & - & 1,47 \\
$\mathrm{CaCl} 2$ & 0,14 & 0,3 & - & - \\
$\mathrm{KH}_{2} \mathrm{PO}_{4}$ & 0,06 & - & - & 0,19 \\
$\mathrm{MgCl}_{2} 6 \mathrm{H}_{2} \mathrm{O}$ & 0,1 & 0,2 & - & - \\
$\mathrm{MgSO}_{4} .7 \mathrm{H}_{2} \mathrm{O}$ & 0,1 & - & - & - \\
$\mathrm{NaHCO}_{3}$ & 0,35 & 1,25 & 0,35 & 1,25 \\
$\mathrm{Na}_{2} \mathrm{HPO}_{4} .7 \mathrm{H}_{2} \mathrm{O}$ & 0,09 & 0,18 & 0,06 & - \\
$\mathrm{NaH}_{2} \mathrm{PO}_{4}$ & - & - & 0,06 & - \\
$\mathrm{D}-\mathrm{glucose}_{\mathrm{KSCN}}$ & 1 & 2 & - & - \\
$\mathrm{KSCN}$ & - & - & - & 0,52 \\
\hline
\end{tabular}

The electrolyte temperature of $37^{\circ} \mathrm{C}$, the temperature of the human body, was achieved and maintained by a Potentiostat MLW U15c (Mesu Lab Instruments, Guangzhou, China), which permanently recirculated the heated water through the cell mantle. Thus, the conditions of experimentation simulated with the conditions encountered in the human body were simulated. In the Ringer solution, at $37^{\circ} \mathrm{C}$, the titanium undergoes an electrochemical passivation in lower than the anodic current recorded in $1 \mathrm{~N}$ sulfuric acid, for the same surface, up to only $1000 \mathrm{mVe} . \mathrm{sc}$.

The passivation performances of the titanium in Ringer's solution are relatively good and justify the use of this material as such, without further processing, when performing medical implants. The area of potential investigated was here wider $-1000 \div 4000 \mathrm{mVe.s.c}$.

In this case, the polarization speed was $100 \mathrm{mV} / \mathrm{sec}$., at the lower limit of the working speeds in cyclic voltammetry. For all samples, three complete cycles, two polarization cycles, 1 and 3, were recorded and evaluated. The analysis considered both recorded polarization cycles. Prior to polarization, all samples were erased with acetone.

\section{SEM Microscopy}

The surface of the samples electrochemical treated and after immersion in Ringer solution were evaluated by Scanning Electron Microscopy (SEM) using Inspect-S Microscope produced by FEI Company. 
PAULA ARGENTINA JIMAN, MARIOARA MOLDOVAN, CODRUTA SAROSI, ALEXANDRINA MUNTEAN, ANDREEA SIMONA POP, VIORICA TARMURE, CATALIN POPA, AUREL GEORGE MOHAN

\section{Viability test of the samples}

Viability test of normal human fibroblasts treated with fully incubated media with Ti and Ti-6Al-4V alloy samples for 24 and $48 \mathrm{~h}$.

Samples were incubated for 24 and $48 \mathrm{~h}$ respectively in complete medium for fibroblasts (DMEM, FCS, ATB), at $37^{\circ} \mathrm{C}, 5 \% \mathrm{CO}_{2}$. Normal human fibroblasts, in the third passage, were cultured on 24-well plates of $3^{*} 10^{4}$ / well and incubated 24 hours in complete culture medium at $37^{\circ} \mathrm{C}, 5 \% \mathrm{CO}_{2}$. The culture medium was removed and the cells were washed twice with PBS. Cells were treated with incubated media at $37^{\circ} \mathrm{C}, 5 \% \mathrm{CO}_{2}$ for $24 \mathrm{~h}$, then washed twice with PBS, enzymatically removed (trypsin / EDTA) from the culture surface and then performed the viability test with trypan blue. The cells were counted in the improved Neubauer room. Viability is expressed as a percentage and results from the ratio of viable cells (which do not capture the dye) to the total number of cells.

Viability $=($ normal cells $/$ total cells $) \times 100$

\section{REFERENCES}

1. D. Bunea, A. Nocivin, Materiale biocompatibile, Ed. BREN, Bucuresti, 1998, pp. 65-74.

2. M. Kulkarni, A. Mazare, P. Schmuki, A. Iglič, Biomaterial surface modification of titanium and titanium alloys for medical applications, in Nanomedicine, One Central Press, United Kingdom, 2014, Chapter 5, pp. 111-136.

3. V. Antoniac, O. Trante, C. Trante, Materiale biocompatibile utilizate la realizarea implanturilor ortopedice, in Buletin Ştiinţific-Conferinţa Naţională de Ştiinţa şi Ingineria Materialelor, BRAMAT'99, 1999, vol. I, ISBN 973-98797-0-5, pp.270273.

4. D. Leordean, S. A. Radu, D. Fratila, P. Berce, Int. J. Adv. Manuf. Tech., 2015, 79, 905-920.

5. M. Bruschi, D. Steinmüller-Nethl, W. Goriwoda, M. Rasse, J. Oral Implantol, 2015, 527426, http://dx.doi.org/10.1155/2015/527426.

6. A.V. Burde, S. Cuc, A. Radu, M.A. Rusu, C.S. Cosma, D. Leordean, Studia UBB Chemia, 2016, 61, 205-214.

7. C. Cosma, N. Balc, M. Moldovan, L. Morovic, P. Gogola, C. Miron-Borzan, J. Optoelectron. Adv. M., 2017, 19, 738-747.

8. S. L. Assis, S. Wolynec, I. Costa, Eletrochim. Acta, 2006, 51, 1815-1819. 
9. T. Chaturvedi T. Indian J. Dent. Res., 2009, 20, 91-98.

10. M. Nica, B. Cretu, D. Ene, I. Antoniac, D. Gheorghita, R. Ene, Materials 2020, 13, 1201; doi:10.3390/ma13051201

11. T.D. Morgan, M. Wilson, J. Appl. Microbiol., 2001, 91, 47-53.

12. M. Hajisafari. A. Z. Bidaki, S. Yazdani, Adv. Mater. Process., 2017, 3, 12-22.

13. S. Cavalu, I. V. Antoniac, L. Fritea, I. M. Mates, C. Milea, V. Laslo, S. Vicas, A. Mohan, J. Adhes. Sci. Technol., 2018, 32, 2509-2522.

14. O. H. Orasan, A. M. Chisnoiu, M. L. Dascalu (Rusu), O. Pastrav, M. Pastrav, M. Moldovan, R. Chisnoiu, Studia UBB Chemia, 2017, 3, 215-223.

15. V.A. Barão, M.T. Mathew, W.G. Assunção, J. C. Yuan, M. A. Wimmer, C. Sukotijo, Clin. Oral Implants Res., 2012, 23, 1055-1062.

16. D. Sucala, C. Sarosi, C. Popa, I. Cojocaru, M. Moldovan, A. G. Mohan, Studia UBB Chemia, 2018, 63, 71-81.

17. C. Castellani, R. A. Lindtner, P. Hausbrandt, Acta Biomater., 2011,7, 432-440.

18. I. Antoniac, Fundamental properties of bioceramics and biocomposites, in Handbook of Bioceramics and Biocomposites, Springer International Publishing, 2016, Vol. 1-2, Chapter 1, pp.35-58.

19. I. Antoniac, C. Sinescu, A. Antoniac, J. Adhes. Sci. Technol., 2016, 30, 17111715.

20. I. Karacan, B. Ben-Nissan, H. A. Wang, A. Juritza, M. V. Swain, W. A. Müller, J. Chou, A. Stamboulis, I. J. Macha, V. Taraschi, Mater. Sci, Eng. C., 2019, 104, 109757.

21. A. Saplontai-Pop, M. Moldovan, R. Oprean, O. Orasan, S. Saplontai, C. Ionescu, Studia UBB Chemia, 2014, 59, 39-46.

22. M. Ahmad, D. Gawronski, J. Blum, J. Goldberg, G. Gronowicz, J. Biomed. Mater. Res., 1999, 46, 121-131.

23. X. Liu, S. Chen, J. K. H. Tsoi, J. P. Matinlinna, Regen. Biomater., 2017, 315. doi: 10.1093/rb/rbx027.

24. J. Curtin, M. Wang, H. Sun, Int. J. Oral Max. Surg., 2017, 46, 94-99.

25. A. D. Tinoco, M. Saxena, S. Sharma, J. Am. Chem. Soc., 2016, 138, 5659-5665.

26. L.Silaghi-Dumitrescu, A. M. Mihailescu, A. Muntean, C. Sarosi, D. Prodan, M. R. Simu, M. Moldovan, A. Kui, M. Pastrav, Studia UBB Chemia, 2019, 4, 107-119.

27. A. Han, J. K. H. Tsoi, F. P. Rodrigues, Int. J. Adhes. Adhes., 2016, 69, 58-71.

28. A. Wennerberg, L. M. Svanborg, S. Berner, Clin. Oral Implants Res., 2013, 24, 203-209.

29. I. M. Hamouda, E. T. Enan, E. E. Al-Wakeel, Int. J. Oral Max. Impl., 2012, 27, 776-784.

30. Y. T. Sul, C. B. Johansson, Y. Kang, Clin. Implant Dent. R., 2002, 4, 78-87.

31. H. Tschernitschek, L. Borchers, W. Geurtsen, Quintessence Int., 2005, 36, 523530.

32. N. Sykaras, A.M. Iacopino, V. A. Marker, Int. J. Oral Max. Impl., 2000, 15, 675690. 
PAULA ARGENTINA JIMAN, MARIOARA MOLDOVAN, CODRUTA SAROSI, ALEXANDRINA MUNTEAN, ANDREEA SIMONA POP, VIORICA TARMURE, CATALIN POPA, AUREL GEORGE MOHAN

33. A. D. Tinoco, M. Saxena, S. Sharma, J. Am. Chem. Soc., 2016, 138, 5659-5665. 34. A. Saplontai-Pop, A.Mot, M. Moldovan, R. Oprean, R. Silaghi-Dumitrescu, O.H. Orasan, S. Saplontai, M.Parvu, G. Emese C. Ionescu, Open Life Sci., 2015, 10, 89-98.

35. S. Chandar, R. Kotian, P. Madhyastha, S. P. Kabekkodu, Padmalatha Rao, J. Indian Prosthodont. Soc., 2017, 17, 35-40. 